\title{
Os Acordos de Basileia e bancos de desenvolvimento no Brasil: uma avaliação do BNDES e do BNB*
}

\author{
Rogério Sobreira** \\ Norberto Montani Martins***
}

Sumário: 1. Introdução; 2. Os Acordos de Basileia no Brasil; 3. Uma avaliação do BNDES e do BNB; 4. Conclusão.

Summary: 1. Introduction; 2. Basel Agreements in Brazil; 3. An Assessment of BNDES and BNB; 4. Conclusion.

Palavras-chave: Bancos de desenvolvimento; Acordos de Basileia; BNDES; Banco do Nordeste do Brasil (BNB); regulação prudencial.

KEY worDs: development banks; Basel agreements; Brazilian Development Bank; Brazilian Northeastern Bank; prudential regulation.

No Brasil, os bancos de desenvolvimento foram submetidos às exigências regulamentares de Basileia e tratados de modo idêntico às demais instituições componentes do sistema financeiro nacional. Contudo, dada a natureza idiossincrática dos bancos de desenvolvimento, frequentemente se argumenta que a aplicação dos acordos a este tipo de instituição não é adequada, tendo por última implicação impedi-las de cumprir suas funções de modo eficaz. Assim, o presente artigo tem por objetivo avaliar se a submissão dos dois principais bancos de desenvolvimento brasileiros, o BNDES e o $\mathrm{BNB}$, aos procedimentos normativos de Basileia provocou uma perda de dinamismo dessas instituições, de modo a impedir integral ou parcialmente o cumprimento de suas funções. Conclui-se que as duas instituições referidas foram afetadas de modo assimétrico pelas exigências regulamentares associadas a Basileia, permitindo ao

\footnotetext{
* Artigo recebido em out. 2010 e aceito em jan. 2011.

** Professor adjunto de economia e finanças da Escola Brasileira de Administração Pública e de Empresas (Ebape) da Fundação Getulio Vargas (FGV). Pesquisador do CNPq. Endereço: Praia de Botafogo, 190, sala 517 - CEP 22250-900, Rio de Janeiro, RJ, Brasil. E-mail: rogerio.sobreira@ fgv.br.

*** Mestrando do Instituto de Economia (IE) da Universidade Federal do Rio de Janeiro (UFRJ). Pesquisador da Ebape/FGV. Endereço: Instituto de Economia. Avenida Pasteur, 250, sala 106 _CEP 22290-240, Rio de Janeiro, RJ, Brasil. E-mail: norberto.martins@gmail.com.
} 
BNDES exercer suas funções com alguma pequena limitação, mas prejudicando fortemente o BNB no exercício de suas funções de banco de desenvolvimento.

Basel Agreements and development banks in Brazil: An Assessment of BNDES and BNB

In Brazil, development banks were subject to the regulatory requirements of Basel Accords and treated similarly to other institutions belonging to the Brazilian financial system. However, given the idiosyncratic nature of development banks it is often argued that the implementation of agreements of this type to these institutions is not adequate, as long as it could prevent them from fulfilling their mission effectively. Therefore, this article aims to assess whether the submission of two major Brazilian development banks, BNDES and BNB, to the Basel regulatory framework caused a loss of dynamism of these institutions in order to prevent full or partial compliance with its functions. We conclude that the two institutions mentioned were affected asymmetrically by the regulatory requirements associated with Basel Accords, allowing the BNDES to exercise its functions with some little limitation, but heavily damaging the BNB in the exercise of its functions as a development bank.

\section{Introdução}

Os Acordos de Basileia representam um marco no que tange às estratégias de regulação bancária aplicadas ao redor do mundo. $\mathrm{O}$ acordo muda o foco regulatório da liquidez para a solvência das instituições financeiras, com base na percepção de que é primordial criar mecanismos que evitassem crises sistêmicas no setor bancário (e seu transbordamento para a economia como um todo). Para tal, estabeleceu-se a exigência de requisitos de capital definidos em função dos riscos dos ativos detidos pelos bancos. O objetivo essencial desta forma de regulação prudencial é que, ao longo do tempo, as trajetórias de expansão do ativo ponderado pelo risco e do capital próprio cointegrem, isto é, evoluam na mesma direção e na mesma magnitude, de modo que, em uma situação extrema, diante de uma súbita desvalorização dos ativos de uma instituição financeira, a mesma seja capaz de honrar suas obrigações com terceiros (notadamente, outros bancos) sem gerar maiores impactos perversos no sistema como um todo. Em outras palavras, este tipo de regulação prudencial representado pelos Acordos de Basileia visa essencialmente reduzir a probabilidade de ocorrência do risco sistêmico. ${ }^{1}$

\footnotetext{
${ }^{1}$ Risco de que um choque numa parte "isolada" do sistema o afete como um todo (De Bandt e Hartmann, 2000).
} 
A despeito do fato de que o Acordo original de 1988 visava a equalizar as condições de competição bancária em nível internacional, contemplando, portanto, somente bancos internacionalmente ativos, ${ }^{2}$ o mesmo foi amplamente adotado e foi aplicado pelos reguladores não só para os bancos "globais", mas também para a totalidade do sistema bancário, no que, diga-se de passagem, foram "auxiliados" pelo Fundo Monetário Internacional (FMI) e pelo Banco Mundial, os quais passaram a exigir a existência do acordo como critério para aprovação de empréstimos (Carvalho, 2005:18). Em que pese o fato de os Acordos de Basileia visarem preferencialmente as instituições que operam o sistema de pagamentos da economia em função da sua importância no desenvolvimento de uma crise sistêmica, os bancos de desenvolvimento também foram sujeitos a estas normas prudenciais, na grande maioria dos países signatários dos Acordos. Estas instituições, como será visto mais adiante, se distinguem das demais instituições financeiras pela sua vinculação direta ou indireta com o processo de desenvolvimento econômico (nacional ou regional), tendo natureza idiossincrática, já que são relacionadas ao processo de desenvolvimento econômico de cada país. Ademais, a aplicação dos Acordos a este tipo de instituição é também inadequada diante do fato de as mesmas não estarem, via de regra, no centro da operação dos sistemas de pagamento e, como tal, não poderem estar relacionadas à emergência de crises sistêmicas (Sobreira, 2009; Sobreira e Zendron, 2011; Prado e Monteiro Filha, 2005; Castro, 2009). Desta forma, as "normas [de Basileia] são, em muitos casos, inadequadas para que [os bancos de desenvolvimento cumpram] com eficácia suas funções legais" (Prado e Monteiro Filha, 2005:1). ${ }^{3}$

No Brasil, as práticas regulamentares sugeridas no primeiro Acordo da Basileia foram adotadas tardiamente, em 1994, dado o conturbado período pelo qual a economia brasileira passava na transição entre as décadas de 1980 e 1990. O Acordo submeteu os bancos de desenvolvimento às exigências regu-

\footnotetext{
${ }^{2}$ Tal fato decorreu da demanda dos bancos norte-americanos que estavam premidos por exigências de requisitos de capital — em um claro resquício do modelo anterior de regulação ainda vigente naquele país àquela época - , enquanto bancos europeus e japoneses não sofriam exigência semelhante, refletindo o estágio mais avançado do processo de desregulamentação financeira observado notadamente em alguns países da Europa ocidental e no Japão, criando, portanto, uma assimetria em favor dos bancos europeus e japoneses.

${ }^{3}$ Esta incompatibilidade entre os Acordos de Basileia e os bancos de desenvolvimento decorre do fato de que tais instituições, que não estão no centro de processos de crises sistêmicas, ao terem de adequar seus modelos de gestão de risco a um modelo que não foi desenhado respeitando suas características acabariam por não serem capazes de desempenhar suas funções a contento e, como tal, deixariam de ser funcionais aos processos de desenvolvimento.
} 
lamentares tratando-os de modo idêntico aos bancos comerciais, universais e demais instituições componentes do sistema financeiro nacional. No desenrolar do processo normativo positivo associado à adoção de Basileia, esperava-se que a solidez do sistema financeiro brasileiro fosse ampliada, o que exigiria, em alguns casos, profundas alterações nos modelos de gestão e nas práticas operacionais das instituições financeiras, de um modo geral, e, mais especificamente, dos bancos de desenvolvimento. A questão que se coloca, no entanto, é se as potenciais alterações derivadas da nova regulamentação implicariam uma perda de dinamismo ou permitiriam aos bancos de desenvolvimento o cumprimento de suas funções.

O presente artigo está organizado como segue. Após esta introdução, a seção 2 apresenta como se deu a implementação do Acordo de Basileia no Brasil. A seção 3 busca avaliar como (ou se) a submissão dos bancos de desenvolvimento brasileiros aqui estudados - o Banco Nacional de Desenvolvimento Econômico e Social (BNDES) e o Banco do Nordeste do Brasil (BNB) - às regras de Basileia - notadamente Basileia $\mathrm{I}$ - , tais como definidas pelo Banco Central do Brasil (BCB), impactou seu comportamento de modo a interferir no cumprimento da sua missão. A seção 4 apresenta as principais conclusões do trabalho.

\section{Os Acordos de Basileia no Brasil}

As proposições regulamentares do Acordo de Basileia de 1988 (BCBS, 1988) começaram a ser introduzidas no Brasil por meio da Resolução 2.099/1994 do Banco Central do Brasil (BCB). Essa resolução estabeleceu os limites mínimos de capital realizado e patrimônio líquido a serem observados pelas instituições financeiras autorizadas a funcionar pelo BCB, incluindo aí os bancos de desenvolvimento (Anexo II, art. 1ㅜㅡ, inciso II), e que as mesmas deveriam "manter valor de patrimônio líquido ajustado compatível com o grau de risco da estrutura de seus ativos" (Anexo IV, art. 1ํ), entre outras disposições.

Ainda no Anexo IV à Resolução, estabeleceu-se o patamar de 8\% para o patrimônio líquido exigido - valor posteriormente alterado para 11\% (Circular 2.784/1997) em consonância com a recomendação do Comitê da Basileia de que países em desenvolvimento, "onde operam sistemas bancários menos desenvolvidos e sujeitos a choques de maior intensidade" (BNDES, 2007:30), adotassem coeficientes mais elevados - e os fatores de ponderação de risco para as diferentes classes de ativos (classificados nas categorias: risco nulo com fator de ponderação $0 \%$, risco reduzido 1: $20 \%$, risco reduzido $2: 50 \%$ e 
risco normal: 100\%). Esta resolução estabeleceu a data de 30 de abril de 1995 como data limite para adaptação das instituições financeiras existentes aos limites de patrimônio líquido definidos na mesma. No caso das instituições criadas após a publicação da Resolução 2.099, o cronograma de implantação permitiu que os bancos brasileiros tivessem até o ano 2001 para se adaptarem plenamente às novas exigências. ${ }^{4}$

Cabe ressaltar que o procedimento de cálculo do patrimônio líquido exigido (PLE) foi alterado algumas vezes (BCB, 2002-10) de modo a incluir outras classes de operações/ativos que implicariam exposição da instituição financeira, tais como operações com swap e ouro. Até então, o Banco Central não havia definido precisamente o conceito de patrimônio líquido que seria aceito para contrastar com o PLE da instituição financeira para fins de análise de seu enquadramento às regras de Basileia. Em 1998, com a edição da Resolução 2.543, a autoridade monetária procede a essa definição ao afirmar que o patrimônio líquido ajustado (PLA) seria composto pela soma dos capitais de nível I e nível II. O capital de nível I seria representado

pelo capital social, reservas de lucros (excluídas as reservas para contingências e as reservas especiais de lucros relativas a dividendos obrigatórios não distribuídos) e lucros ou prejuízos acumulados ajustados pelo valor líquido entre receitas e despesas, deduzidos os valores referentes a ações em tesouraria, ações preferenciais cumulativas e ações preferenciais resgatáveis (BCB, 1998).

O capital de nível II, por seu turno, seria representado "pelas reservas de reavaliação, reservas para contingências, reservas especiais de lucros relativas a dividendos obrigatórios não distribuídos, ações preferenciais cumulativas, ações preferenciais resgatáveis, dívidas subordinadas e instrumentos híbridos de capital e dívida" (BCB, 1998). Adicionalmente, o BCB informa limites importantes relativos à integralização do capital de nível II para composição do PLA, quais sejam: (a) o montante do capital de nível II fica limitado ao valor do nível I; (b) o montante das reservas de reavaliação fica limitado a $25 \%$ do PLA; e (c) o montante das dívidas subordinadas fica limitado a 50\% do capital de nível I.

\footnotetext{
${ }^{4}$ A Resolução 2.212/1995 estabelece que o Patrimônio Líquido Exigido (PLE) das novas instituições deveria corresponder a $32 \%$ do ativo ponderado pelo risco (APR) nos dois primeiros anos a partir do início do seu funcionamento, a $24 \%$ do APR de dois a quatro anos de seu funcionamento, a $16 \%$ do APR de quatro a seis anos do seu funcionamento e, finalmente, a $8 \%$ do APR - conforme determinado pela Resolução 2.099 - a partir do sexto ano do seu funcionamento.
} 
Esta definição de PLA é alterada em dezembro de 2000 com a edição da Resolução 2.802, que substitui a definição de PLA por Patrimônio de Referência (PR) para fins de análise de enquadramento da instituição financeira às regras de Basileia. Com esta resolução, o capital de nível I passa a ser representado

pelo patrimônio líquido, acrescido do saldo das contas de resultado credoras e deduzido do saldo das contas de resultado devedoras, excluídas as reservas de reavaliação, as reservas para contingências e as reservas especiais de lucros relativas a dividendos obrigatórios não distribuídos e deduzidos os valores referentes a ações preferenciais cumulativas e a ações preferenciais resgatáveis (BCB, 2000).

O capital de nível II, por seu turno, passa a ser representado "pelas reservas de reavaliação, reservas para contingências, reservas especiais de lucros relativas a dividendos obrigatórios não distribuídos, ações preferenciais cumulativas, ações preferenciais resgatáveis, dívidas subordinadas e instrumentos híbridos de capital e dívida" (BCB, 2000). A integralização de capital de nível II continua limitada pelo BCB ao valor do capital de nível I, observando-se que (a) o montante das reservas de reavaliação fica limitado a $25 \%$ do PR; (b) o montante das dívidas subordinadas, somado ao valor das ações preferenciais resgatáveis de prazo de vencimento inferior a 10 anos, fica limitado a 50\% do capital nível I; e (c) sobre o valor das dívidas subordinadas é aplicado um redutor de $20 \%$ a cada ano nos últimos cinco anos anteriores ao respectivo vencimento da dívida. Em 2001, com a publicação da Resolução 2.837, a definição de Patrimônio de Referência (PR) foi mais uma vez modificada, embora de modo pontual. ${ }^{5}$

As mudanças implementadas a partir da edição da Resolução 2.099/1994 e a consequente necessidade de reestruturação patrimonial dos bancos levaram o governo a implementar um programa de fortalecimento das instituições financeiras federais. Com a edição da Resolução 2.682/1999, que obrigava

\footnotetext{
${ }^{5}$ Essencialmente, a Resolução 2.837/2001 versa sobre uma exceção referente ao limite de aplicação de recursos no ativo permanente de que trata a Resolução 2.283/96, a qual, por seu turno, afirma que "o total dos recursos aplicados no Ativo Permanente não pode ultrapassar $90 \%$ (noventa por cento) do valor do patrimônio líquido ajustado na forma da regulamentação em vigor (PLA) das instituições financeiras e demais instituições autorizadas a funcionar pelo Banco Central do Brasil". Assim, de acordo com a Resolução 2.837/2001, o PLA referido na Resolução 2.283/96 deve ser acrescido das contas de resultado credoras e deduzido o saldo das contas de resultado devedoras.
} 
as instituições financeiras a classificar as operações de crédito para fins de constituição de provisão para créditos de liquidação duvidosa, as instituições financeiras se viram obrigadas não só a elevar a referida provisão quando fosse o caso, mas também a constituir um volume de capital próprio eventualmente superior àquele constituído antes da edição da resolução. No que se refere especificamente aos bancos públicos federais, em uma Inspeção Global Consolidada (IGC) ${ }^{6}$ feita em 1997 pelo Banco Central em cada um dos quatro bancos federais - Caixa Econômica Federal, Banco do Brasil, Banco do Nordeste e Banco da Amazônica ${ }^{7}$ —, foi constatada a necessidade de reestruturação patrimonial destas instituições. ${ }^{8,9}$

Em função do resultado desta Inspeção e das provisões exigidas a partir da edição da Resolução 2.682/1999, o governo percebeu a necessidade de instituir um programa de ajuste patrimonial destas instituições, o que foi feito com a edição da Medida Provisória (MP) 2.196, de 28 de junho de 2001, a qual cria também a Empresa Gestora de Ativos - Emgea, que tem a responsabilidade de administrar os créditos cedidos pelos bancos públicos federais objeto do programa. O Programa de Fortalecimento das Instituições Financeiras Federais (Proef) consistiu, basicamente, (a) da transferência do risco dos créditos de liquidação duvidosa e com baixa remuneração para o Tesouro Nacional e/ou para a Emgea; (b) da troca de ativos de pouca liquidez e baixa remuneração por ativos líquidos remunerados à taxa de mercado; e (c) do aumento de capital de três dessas instituições. ${ }^{10}$

\footnotetext{
${ }^{6}$ A IGC foi realizada no âmbito da implementação do Acordo de Basileia no Brasil, seguindo os princípios de supervisão bancária definidos pelo BIS. A Resolução 2.302/1996 é o normativo que efetivamente institui a rotina das referidas inspeções.

${ }^{7}$ O BNDES não foi enquadrado no grupo de instituições federais que apresentavam necessidade de reestruturação patrimonial diante do fato de sua carteira de crédito ser hegemonicamente classificada como AA por ocasião da publicação da Resolução 2.682/1999.

${ }^{8} \mathrm{~A}$ implementação do Acordo de Basileia no Brasil, no que tange à adequação patrimonial das instituições financeiras, levou à necessidade de aumento do capital por parte das mesmas em função (a) da elevação do limite mínimo para adequação do capital de $8 \%$ para $11 \%$; (b) do aumento do percentual de ponderação de risco sobre créditos tributários de $20 \%$ para $300 \%$; e (c) da definição de novos critérios de classificação de risco de crédito e de novos níveis de provisão para assegurar solidez às instituições.

${ }^{9}$ Especificamente, na "Inspeção Global Consolidada, o Banco Central constatou a presença expressiva no ativo dos quatro bancos federais de créditos de baixa remuneração e/ou difícil recuperação. Esses créditos correspondem a empréstimos de longo prazo com elevado grau de subsídios jamais explicitados orçamentariamente [...]" (Ministério da Fazenda, 2001a).

${ }^{10}$ Especificamente, foram capitalizados a Caixa Econômica Federal, o Banco da Amazônia e o Banco do Nordeste.
} 
Especificamente no que diz respeito ao Banco do Nordeste, as medidas contidas na MP e seus impactos sobre a necessidade de capital do banco implicaram provisionamento (Ministério da Fazenda, 2001b): (a) de R $\$ 1,375$ bilhão em função da reclassificação de operações de carteira própria pré-1995; (b) de R 395 milhões para cobrir valores compensados do Imposto de Renda e Contribuição Social pagos em decorrência do expurgo inflacionário; (c) de $\mathrm{R} \$ 30$ milhões para fazer frente a ajustes e reavaliações dos níveis de provisionamento para contingências fiscais cíveis e trabalhistas e efetivação das despesas diferidas provenientes de processo de reestruturação organizacional; (d) de cerca de $\mathrm{R} \$ 300$ milhões decorrente do reenquadramento do Fundo Constitucional de Financiamento do Nordeste (FNE), a partir de dezembro de 1998, como de risco 50\% nos moldes da classificação instituída pela Resolução 2.682/1999. Adicionalmente, o Banco foi chamado a elevar sua base de capital pela incorporação de parcela dos recursos do FNE como capital de nível II, respeitados os limites fixados pelas autoridades reguladoras, bem como promoveu a uniformização de procedimentos contábeis de reconhecimento de riscos e enquadramento às novas regras prudenciais que, embora sem repercussão na estrutura de capital da instituição, levou a mesma a promover ajustes na carteira de clientes.

Vale ressaltar, por fim, que o Brasil aderiu formalmente aos procedimentos sugeridos pelo Novo Acordo de Basileia (BCBS, 2004) em 2004 (Comunicado $12.746 / 2004$ ), ainda que a aplicação prática do novo acordo só seja editada pelo Comunicado 16.137/2007. Como o cronograma de implementação se estende de 2008 até 2012, seus efeitos ainda não puderam ser verificados adequadamente. Desta forma, este processo não será analisado neste trabalho. ${ }^{11}$

\section{Uma avaliação do BNDES e do BNB}

Como indicado na introdução, o presente artigo tem por objetivo avaliar empiricamente se a introdução dos Acordos de Basileia no Brasil representou algum limite, tácito ou explícito, à execução das missões atribuídas ao BNDES e $\mathrm{BNB}$, em decorrência de possíveis alterações nas suas estruturas de gerenciamento de risco e, consequentemente, na estrutura de balanço dessas instituições, notadamente no que diz respeito à capacidade para conceder crédito de longo prazo.

O BNDES tem por missão, definida em seu estatuto social, "promover o desenvolvimento sustentável e competitivo da economia brasileira, com geração

\footnotetext{
${ }^{11}$ Sobre a implementação de Basileia 2 no Brasil, ver BCB (2010a) e Castro (2009: cap. 4).
} 
de emprego e redução das desigualdades sociais e regionais" (BNDES, 2010, grifos nossos). Como instituição financeira híbrida, o banco atua principalmente no mercado de crédito de longo prazo e em projetos de larga escala, assumindo também funções de natureza macroeconômica — planejamento, formulação e/ ou execução de políticas nacionais. Já o BNB tem por missão "atuar, na capacidade de instituição financeira pública, como agente catalisador do desenvolvimento sustentável do Nordeste, integrando-o na dinâmica da economia nacional" (BNB, 2009, grifos nossos). Assim como o BNDES, o BNB atua principalmente no mercado de crédito de longo prazo, ainda que se possa destacar a atuação do banco em outros mercados, como o de microcrédito, e assume também funções de natureza macroeconômica, só que em âmbito regional.

Vale destacar que ambos os bancos são de controle majoritário da União Federal (sendo a mesma proprietária de 100\% das ações do BNDES e de $94,2 \%$ das ações do BNB) e que, destarte, a principal fonte estável de funding destas instituições diz respeito a recursos públicos, especialmente, de recursos públicos advindos de fundos parafiscais (sendo que os repasses do Tesouro Nacional ganham destaque no biênio 2009/10). De um lado, o BNDES tem como fonte (pública e estável) principal de funding o Fundo de Amparo ao Trabalhador (FAT), constituído de uma parcela do lucro das empresas que forma um fundo em benefício dos trabalhadores, custeando programas como o seguro-desemprego e o abono salarial e financiando demais programas que fomentem a qualidade e o volume de emprego. Neste sentido, $40 \%$ dos recursos ligados ao FAT passaram a ser direcionados para as aplicações do BNDES (art. 239 da Constituição Federal de 1988). Por outro lado, o BNB conta com o Fundo Constitucional de Financiamento do Nordeste (FNE) como principal fonte (pública e estável) de funding. Os recursos do FNE provêm da alíquota de 1,8\% da arrecadação pela União do imposto sobre renda e proventos de qualquer natureza (IR) e do imposto sobre produtos industrializados (IPI), além dos retornos de suas aplicações.

De modo a avaliar adequadamente os impactos da implementação do Acordo da Basileia no BNDES e no BNB, tomamos como período de análise o intervalo que vai do ano de 1998 ao primeiro semestre de 2010. Tal escolha nos permite evitar a fase de alta inflação da economia brasileira, a qual poderia levar a distorções na análise aqui executada, notadamente pelo fato de as incertezas associadas a esse período impactarem negativamente a capacidade e disposição dos empreendedores em realizar investimentos de mais longo prazo. Adicionalmente, foi evitado o período que vai de meados de 1994 ao final de 1997 diante do fato de o mesmo ser um período de transição no que se refere à adaptação às regras de Basileia (e.g., as fórmulas de cálculo do patrimônio líquido exigido [PLE] são alteradas diversas vezes no período, o 
cronograma de implementação também sofre várias alterações, assim como os procedimentos contábeis aceitos pelo Banco Central do Brasil) e, last but not least, pela indisponibilidade de informações.

A estratégia regulatória presente nos Acordos da Basileia sugere que as trajetórias de expansão do ativo ponderado pelo risco e do patrimônio de referência devem cointegrar, de modo que determinada instituição seja capaz de honrar suas obrigações sem gerar impactos perversos no sistema financeiro. Ainda que o primeiro Acordo da Basileia tenha natureza essencialmente tutelar, observase que, no Brasil, as instituições financeiras têm uma série de incentivos para manter os índices de Basileia elevados, excedendo o exigido pelo ente regulador, notadamente em decorrência das elevadas taxas de juros pagas pelos títulos da dívida pública que permite às mesmas construir uma reputação de solidez junto ao regulador e ao mercado sem, contudo, incorrer em elevados custos por manter percentuais elevados do seu ativo em obrigações que compensam o menor risco de não pagamento, ofertando uma taxa de retorno suficientemente mais reduzida do que aquelas observadas em obrigações (ativos) de maior risco.

Neste contexto, os efeitos esperados da submissão dos bancos aqui estudados aos Acordos, e mais especificamente o estabelecimento da exigência de coeficientes de capital, se fazem sentir essencialmente em duas frentes: (i) maior concentração das carteiras de ativos em ativos de baixo risco e maior liquidez - criando-se, neste sentido, uma tendência a uma menor disposição a ofertar crédito de longo prazo em prol da aquisição de títulos públicos -, de modo a reduzir a cifra do ativo ponderado pelo risco e, portanto, o patrimônio de referência exigido; e (ii) elevação do capital próprio e redução do grau de alavancagem com que os bancos devem operar, de modo a elevar o patrimônio de referência a ser comparado com o patrimônio exigido.

Isto posto, o artigo elenca as seguintes "hipóteses nulas" a serem examinadas em relação ao BNDES e ao BNB, as quais replicam os impactos esperados da implementação dos Acordos de Basileia: (1) a parcela das operações de crédito sobre o ativo total tende a diminuir/se estagnar; (2) no conjunto das operações de crédito, as operações de maior liquidez/menor risco tendem a se elevar; (3) a parcela de títulos públicos tende a aumentar; (4) a parcela do patrimônio líquido deve cointegrar com a expansão do ativo ponderado pelo risco; (5) o montante de passivos de capital de nível II (e.g., dívida subordinada) tende a se elevar.

\subsection{Banco Nacional de Desenvolvimento Econômico e Social (BNDES)}

O BNDES apresentou índices de Basileia que superaram com folga o valor exigido pelo Banco Central (11\%) ao longo de todo o período 2001-10 (gráfico 
1). Duas reduções substanciais neste indicador foram constatadas, no entanto. A primeira, entre os anos de 2001 e 2002, em função da redução do patrimônio de referência de capital de nível II devido à caracterização do FAT Constitucional como dívida subordinada (Resolução 2.837/2001) — limitando, portanto, o seu valor a 50\% do patrimônio líquido ajustado (antes da emissão deste normativo, o valor elegível a capital poderia alcançar 100\% do PLA — gráfico A.1). A segunda redução, ocorrida entre os anos de 2007 e 2008, foi uma decorrência direta das medidas anticíclicas adotadas pelo governo para fazer frente aos efeitos da crise financeira internacional de 2007/08. ${ }^{12}$ Por um lado, houve forte expansão dos empréstimos do banco (média de 31,4\% de crescimento real no biênio 2008/09) e, por outro, uma significativa elevação dos empréstimos e repasses do Tesouro para o banco (que passaram a constituir a principal parcela do funding do banco, superando o FAT). ${ }^{13}$

\section{Gráfico 1}

BNDES: índice de Basileia (2001-10)*

Patrimônio de referência/ativos ponderados pelo risco (\%)

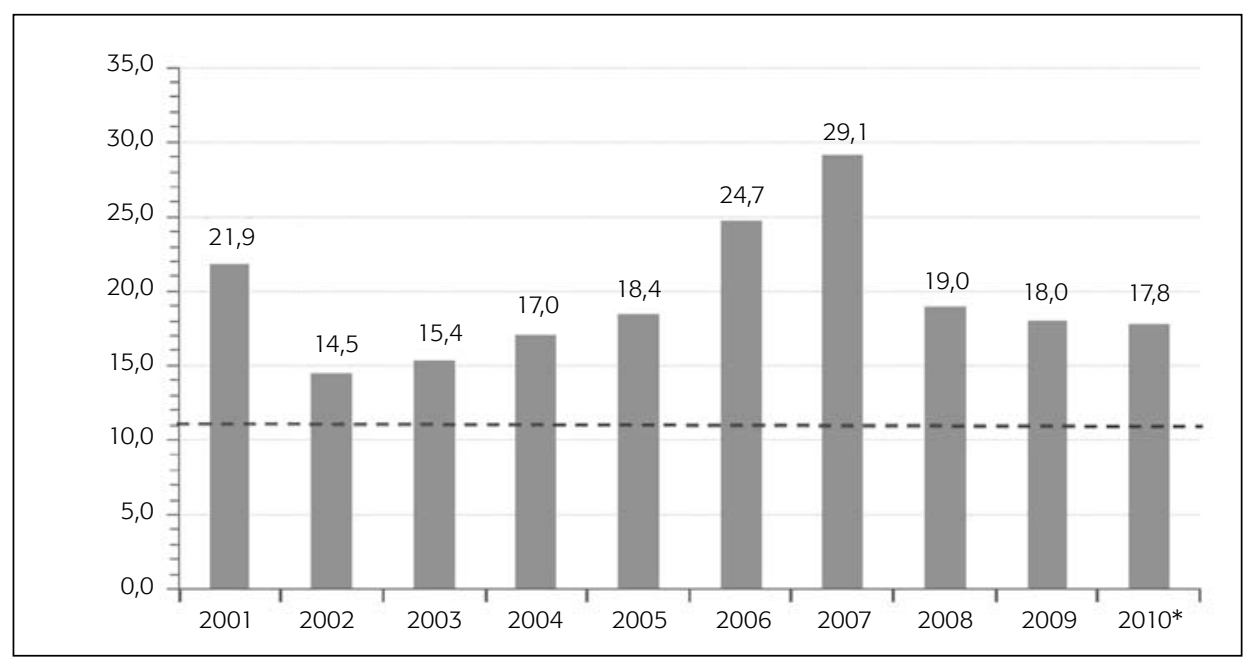

Fonte: BCB, 2001-10. * Primeiro semestre de 2010.

\footnotetext{
${ }^{12}$ Para maiores detalhes sobre essas medidas, ver Sobreira e Paula (2010).

${ }^{13}$ Vale lembrar que, enquanto o FAT é contabilizado como uma dívida subordinada e entra, portanto, no patrimônio de referência utilizado como base de comparação para fins de Basileia, os empréstimos e repasses do Tesouro constituem capital de terceiros e não entram nesta contabilidade.
} 
A despeito destas reduções, a "folga" observada no índice de Basileia do banco sugere que o BNDES não foi profundamente afetado na execução da sua missão. Sem embargo, no período 1998-2007 houve uma contínua elevação da parcela de operações de crédito (e repasses) (gráfico 2), diferentemente do esperado a partir da implementação do Acordo. Em outras palavras, a elevação do índice de Basileia do banco foi acompanhada de uma expansão do crédito, o que parece indicar que a política de crédito executada pelo banco foi estruturada de modo a comportar a ampliação dos empréstimos sem que, como contrapartida, houvesse pressões sobre o patrimônio de referência exigido pelo regulador. $\mathrm{O}$ binômio expansão das operações indiretas (repasses interfinanceiros)-manutenção/elevação da parcela de tomadores de boa qualidade (investment grade) na carteira norteou a estratégia operacional do banco no período.

\section{Gráfico 2}

BNDES consolidado: ativo - contas selecionadas (1998-10)*

Participação \% em relação ao total do ativo

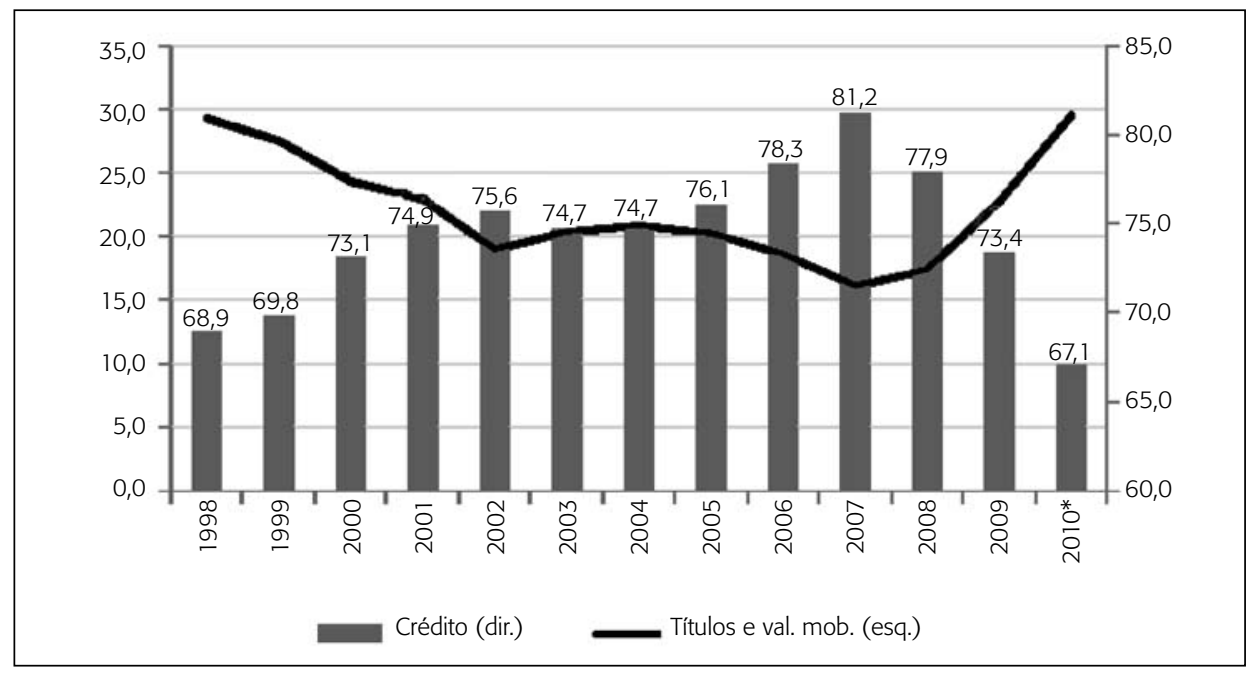

Fonte: Elaboração própria a partir de dados do BNDES. * Primeiro semestre de 2010.

Neste sentido, percebe-se que, ao longo do referido período, as operações de crédito indiretas, intermediadas por instituições financeiras credenciadas junto ao BNDES, se elevaram e atingiram $48,9 \%$ do total de empréstimos em 2007 (gráfico 3). Do ponto de vista de Basileia, basear a estratégia de expansão dos empréstimos em operações indiretas faz com que o risco de crédito seja substituído pelo risco de contraparte, ao qual está associado um menor 
fator de ponderação para o cálculo do Ativo Ponderado pelo Risco (APR), isto é, o fator multiplicador $F$ ' dos repasses interfinanceiros no cálculo do Ativo Ponderado pelo Risco é inferior ao fator multiplicador $F$ das operações diretas de crédito. ${ }^{14}$ Ademais, ao utilizar mais intensamente a rede de intermediários financeiros, o BNDES acaba ampliando o universo potencial de tomadores de empréstimos, os quais por serem de montantes inferiores àqueles observados para as operações diretas (até $\mathrm{R} \$ 10$ milhões) acabam por reduzir a concentração da carteira total de empréstimos do banco e, em última instância, diminui seu risco sistemático, colaborando assim para uma não elevação do patrimônio de referência vis-à-vis a expansão do crédito. Este movimento é reforçado pela tendência à concentração da carteira total de crédito em ativos de menor risco e maior liquidez ao longo do período 1998-2007, os quais exigem menores provisões para risco de crédito (o que reduz o valor do APR). Tal fato é evidenciado pela elevada parcela dos créditos investment grade (de classificação AA, A e B) no total da carteira do banco, chegando mesmo a representar mais de $92 \%$ do crédito total ao final de 2007 (gráfico 4).

\section{Gráfico 3}

BNDES: repasses e operações de crédito (2002-10)*

Participação \% dos repasses em relação ao total de empréstimos

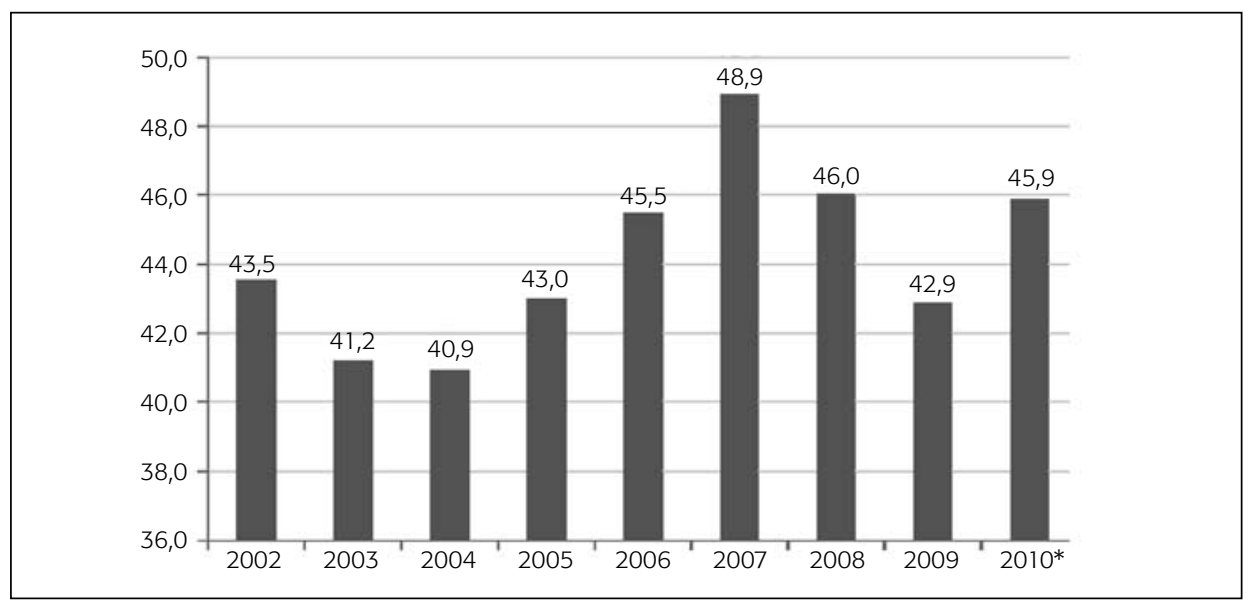

Fonte: Elaboração própria a partir de dados do BNDES. * Primeiro semestre de 2010.

\footnotetext{
${ }^{14}$ De acordo com a Resolução 2.099/1994, a rubrica "Créditos decorrentes de repasses de recursos a outras instituições financeiras", posteriormente denominada "Repasses Interfinanceiros", estava associada a um fator de ponderação de risco de $50 \%$ (risco reduzido), enquanto a rubrica "Operações de Crédito" estava associada a um fator de 100\% (risco normal).
} 


\section{Gráfico 4}

BNDES: repasses e operações de crédito (2001-09)

$\%$ das operações investment grade (AA, A e/ou B) em relação ao total da carteira

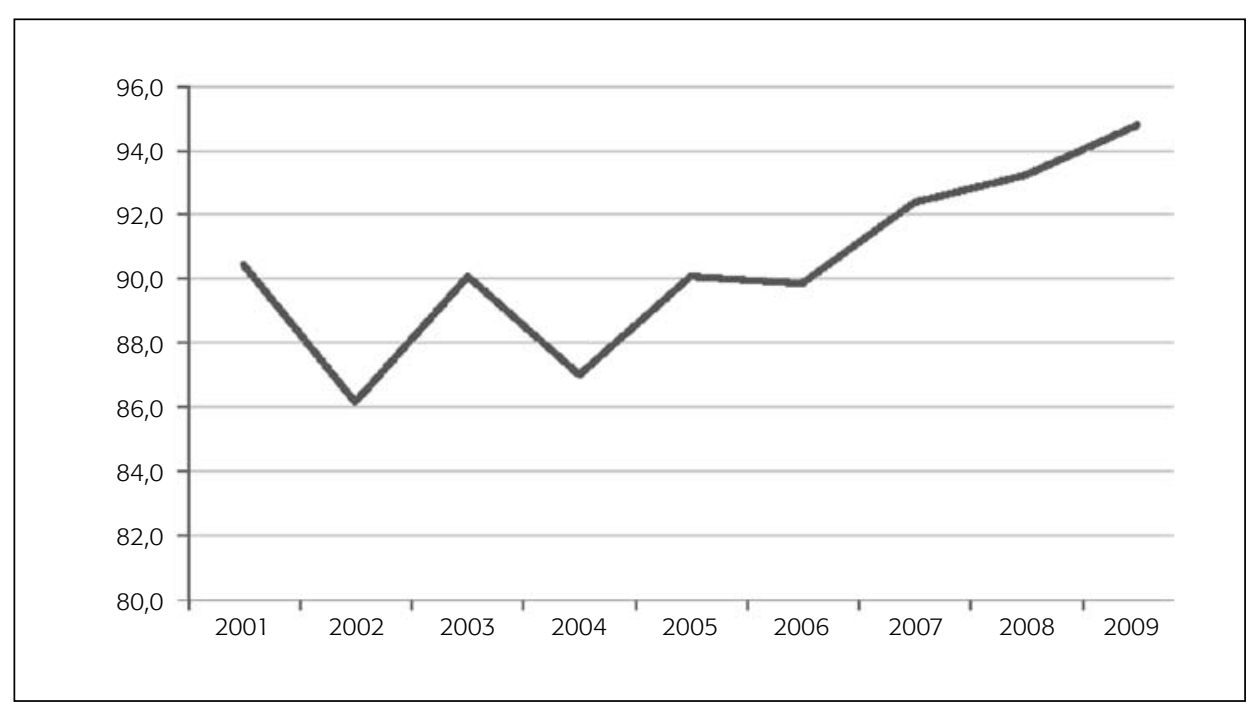

Fonte: Elaboração própria a partir de dados do BNDES.

O ano de 2008, por sua vez, marca a consolidação de uma nova política de concessão de crédito do banco, que vigorou a partir de então, qual seja, as operações diretas elevam sua participação no total das operações de crédito, mantendo-se a tendência à expansão dos créditos investment grade. O BNDES assume neste ano a função de agente do governo para o financiamento do Programa de Aceleração do Crescimento (PAC) e dos investimentos ligados à exploração do pré-sal - e, no período mais recente, para financiar obras ligadas à Copa do Mundo - , tendo sua política de crédito se reorientado para atender às demandas do setor de infraestrutura. ${ }^{15}$ Adicionalmente, a crise de 2007/08 exigiu que o BNDES assumisse algumas operações diretamente, em especial, o financiamento dos setores exportadores. ${ }^{16}$

\footnotetext{
${ }^{15}$ As empresas tomadoras de crédito direto junto ao BNDES são, naturalmente, empresas de grande porte e, via de regra, possuem uma classificação de risco (rating) elevada. Tal fato, por si só, colabora para o aumento da participação dos créditos investment grade no total das operações de crédito do banco, com impactos positivos sobre o índice de Basileia.

${ }^{16}$ Entre 2008 e 2010, o BNDES desembolsou US\$26,2 bilhões para exportação, um crescimento de $60 \%$ em relação ao triênio anterior. Este valor é extremamente significativo se tomarmos por
} 
Em que pese o crescimento das operações diretas - e a expansão absoluta do crédito em decorrência da expansão do funding do Banco — , a participação do crédito no total do ativo do banco se reduziu neste período. Em contrapartida, observou-se uma expansão significativa na participação de títulos públicos no total do ativo, a qual sai de 0,5\% em 2007 para nada menos que $18,1 \%$ no primeiro semestre de 2010 (gráfico 5). Tal fato parece estar relacionado à estratégia do banco de combinar uma expansão absoluta do crédito com um índice de Basileia algo estável após a substantiva queda observada a partir de 2008.

Sem embargo, a maior participação relativa de títulos públicos no total do ativo indica que os mesmos se expandiram mais intensamente que a elevação observada no funding, fato que permite ao BNDES compensar a elevação do ativo ponderado pelo risco derivada da expansão do crédito direto. Assim, neste segundo período de análise, parecem existir evidências de que a submissão do BNDES aos Acordos de Basileia imprimiu algum tipo de limitação à política operacional do banco, já que a elevação das operações de crédito permitida pela substantiva elevação do seu funding necessitou ser acompanhada por uma elevação da parcela de títulos públicos. Caso a estratégia observada anteriormente à queda no índice de Basileia houvesse sido mantida, a taxa real de expansão das operações de crédito poderia ter sido cerca de 10 pontos percentuais superior à observada nos anos de 2008 e 2009 e de dois pontos percentuais em relação à taxa observada em 2010 (gráfico A.2, no anexo).

No que diz respeito às operações pelo lado do passivo, a política operacional do BNDES parece ter apresentado maior autonomia em relação a Basileia relativamente ao constatado pelo lado do ativo, ao menos em relação ao período recente (2008-10). Mesmo levando em conta a já referida redução da rubrica do patrimônio de referência relativa ao capital de nível II (Resolução 2.837/2001), não há indícios de uma política deliberada por parte do banco no sentido de elevar a parcela de capital próprio em relação ao total do passivo, ou mesmo de estabelecer uma trajetória de expansão do patrimônio de referência concomitantemente à elevação do ativo ponderado pelo risco. Tal fato fica evidente quando se percebe que, na maior parte do período, o ativo se expandiu a taxas mais aceleradas que o patrimônio de referência. Entre os anos de 2005 e 2007, contudo, ocorreu precisamente o oposto, tendo o patrimônio de referência se elevado a taxas mais elevadas que o ativo, notadamente em função da expansão dos lucros acumulados no período (tabela A.2, no anexo). ${ }^{17}$

referência a variação das concessões de crédito à exportação (ACC) realizadas pelo setor privado, as quais recuaram $18,4 \%$ no mesmo período.

${ }^{17}$ Diante do maior crescimento econômico observado neste período e, consequentemente, menor pressão sobre as contas públicas - o que se traduziu em uma maior margem de manobra para perseguição das metas de superávit primário - , o BNDES pôde deixar de repassar lucros ao Tesouro Nacional e contabilizá-los como capital próprio em seu passivo (a parcela de lucros acumulados 
Gráfico 5

BNDES: ativo - contas selecionadas (1998-10)* Participação \% dos títulos públicos em relação ao total do ativo

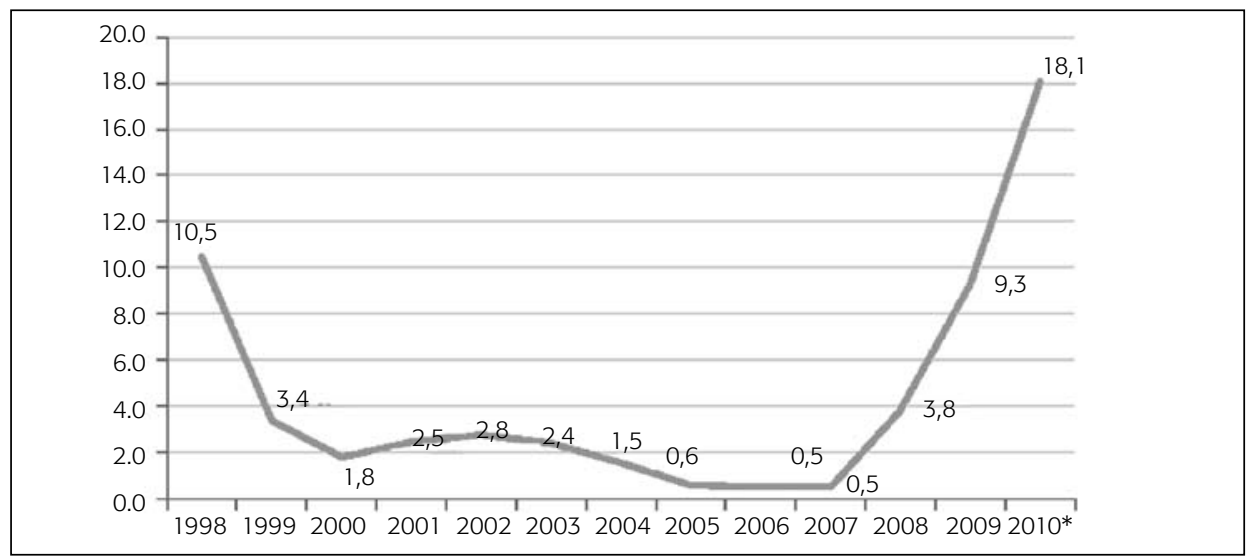

Fonte: Elaboração própria a partir de dados do BNDES. * Primeiro semestre de 2010.

Gráfico 6

BNDES: passivo - contas selecionadas (1998-10)*

Variação \% real no ano (IPCA)

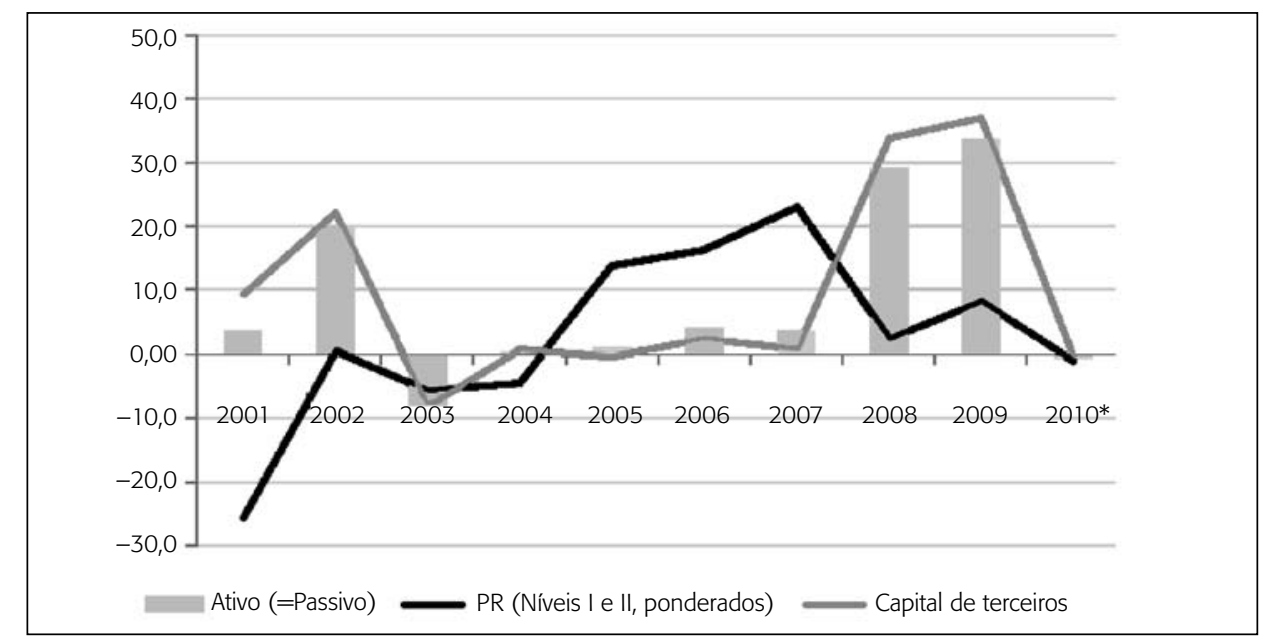

Fonte: Elaboração própria a partir de dados do BNDES. * Primeiro semestre de 2010.

atingiu 4,8\% do passivo em 2007, ante 0,7\% em 2004). Esta "nova" estratégia pode estar ligada a uma tendência de diversificação das fontes de recursos do BNDES (Prochnik e Machado, 2008), dado o esgotamento relativo do FAT ante as necessidades do banco (Giambiagi, Rieche e Amorim, 2009), mas não parece ter relação direta com o fato de o banco ter se ajustado mais fortemente aos requisitos de Basileia. 
A partir de 2008, em decorrência da crise financeira internacional, a taxa de crescimento da parcela referente ao capital de terceiros se amplia substantivamente em consequência da elevação dos repasses do Tesouro Nacional ao BNDES com vistas à atuação anticíclica diante da crise e, como já citado, ao financiamento de projetos definidos como prioritários pelo governo, em especial, aqueles ligados à exploração do pré-sal. Entre 2008 e 2010, o BNDES também passa a recorrer de modo mais intenso a captações em mercado, como pode ser observado no gráfico 7. Neste período, a imposição de um índice de Basileia nunca inferior a $11 \%$ poderia ter implicado um ajuste na estrutura do passivo do banco. Contudo, como observado, tal ajuste se fez essencialmente nas operações ativas. Ademais, considerando que o índice de Basileia do banco nunca foi inferior a $11 \%$, a estratégia implementada em relação às operações ativas do banco visaram a evitar uma queda mais substantiva do referido índice do que refletiram a necessidade de ajustamento a este valor.

Em síntese, a observância do BNDES aos princípios normativos de Basileia não impediu o banco de executar suas funções de modo satisfatório, permitindo que o mesmo mantivesse uma estratégia operacional relativamente autônoma diante das exigências regulamentares, notadamente no que se refere à gestão do seu passivo, embora tenha sido observada a emergência de algumas limitações à estratégia creditícia do banco, especialmente a partir de 2008. Assim, a tendência à elevação da parcela de tomadores investment grade na carteira do banco parece ter estado ligada à necessidade de manter controlado o ativo ponderado pelo risco de modo a evitar expansões mais substantivas no patrimônio de referência exigido, embora, a priori, tal fato não tenha se mostrado incompatível com as funções atribuídas ao banco. ${ }^{18} \mathrm{~A}$ menor expansão das operações de crédito em relação à evolução do funding entre 2008 e 2010 também parece ter sido um resultado desta limitação.

\footnotetext{
${ }^{18}$ Fatores idiossincráticos, como os descritos na nota 15 , parecem ser mais relevantes na determinação deste resultado.
} 


\section{Gráfico 7}

BNDES: passivo - contas selecionadas (2000-10)*

R\$ milhões de junho de 2010 (IPCA)

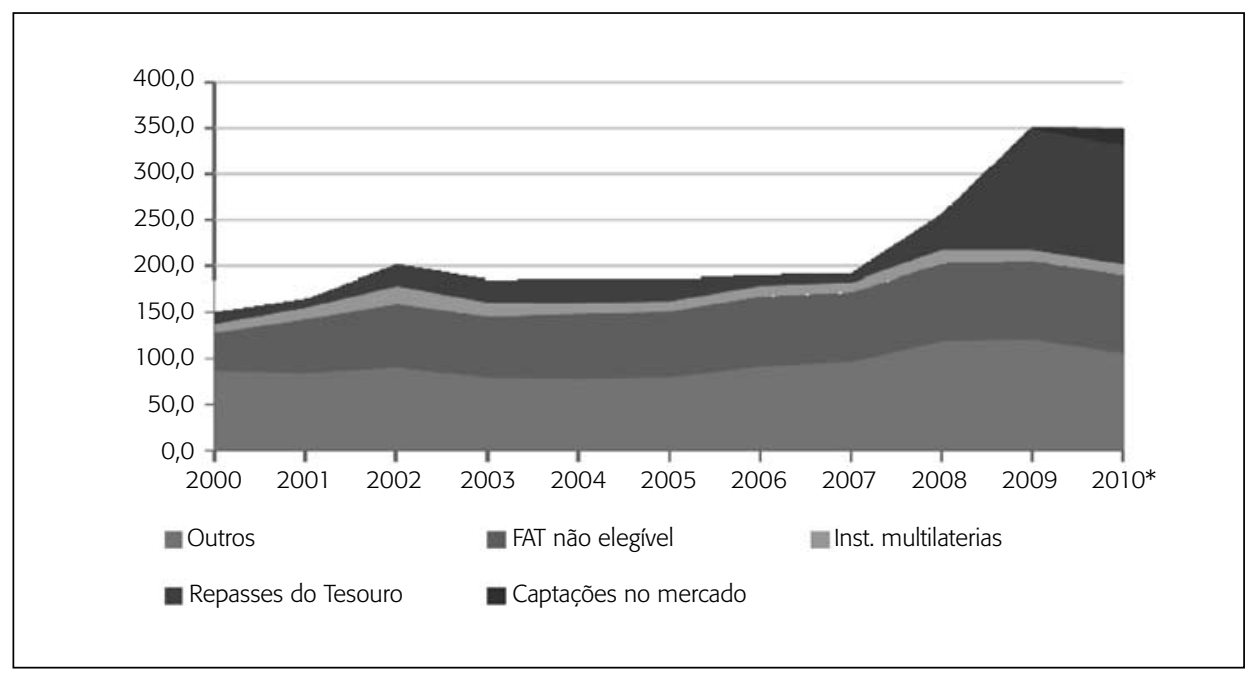

Fonte: Elaboração própria a partir de dados do BNDES. * Primeiro semestre de 2010.

\subsection{Banco do Nordeste do Brasil (BNB)}

A edição de novas normas regulamentares de Basileia ao longo dos anos de 1999 e 2000 teve para o BNB uma implicação imediata na forma da segregação do seu patrimônio e aquele do FNE a partir de então, levando o índice de Basileia do banco a ficar abaixo do limite estabelecido pelo BCB nestes anos (gráfico 8). Como observado, tal situação implicou a inclusão do BNB no Proef, cujas principais medidas saneadoras contemplaram: (i) um aumento de capital social da ordem de $\mathrm{R} \$ 2,1$ bilhões; (ii) a assunção do risco das operações de crédito rural (no valor de $\mathrm{R} \$ 49,2$ milhões) pela União, por meio da troca de ativos entre o banco e o Tesouro Nacional; (iii) o repasse de recursos do FNE para o BNB, passíveis de constituir capital de nível II nos termos de Basileia; e (iv) a desobrigação do risco de crédito das operações do FNE contratadas até o final de novembro de 1998 (BNB, 2001:8-9; MP nº 2.196-3/2001; Ministério da Fazenda, 2001a e 2001b). 


\section{Gráfico 8}

BNB: índice de Basileia (2001-10)*

Patrimônio de referência/ativos ponderados pelo risco (\%)

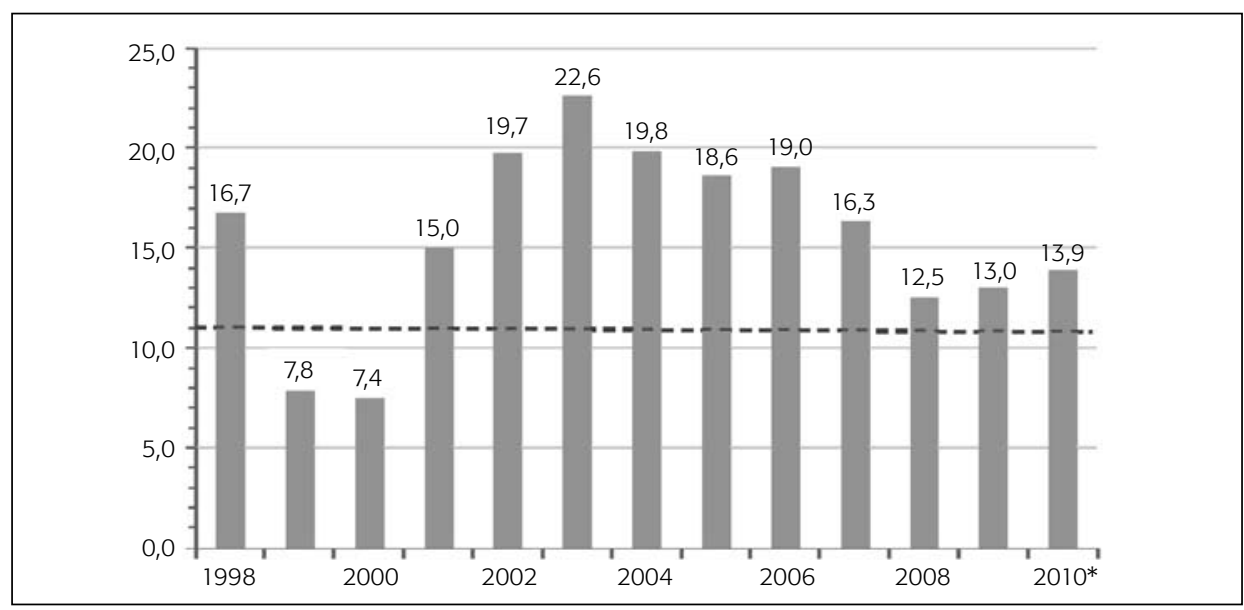

Fonte: BCB, 2001-10. * Referente ao primeiro semestre de 2010.

Os primeiros impactos da inclusão do BNB no Proef se fizeram sentir, pelo lado do ativo, na redução de 44,6\%, em termos reais, das operações de crédito e repasses interfinanceiros entre 2000 e 2002 (gráfico 9). Tal fato representou uma queda de 28,8 pontos percentuais da parcela de empréstimos sobre o ativo (gráfico 10) e uma ampliação de 347,4\%, em termos reais, da parcela de títulos e valores mobiliários (dos quais cerca de $85 \%$ dizem respeito a títulos públicos) no total do ativo neste período. ${ }^{19}$

O Proef permitiu ainda que, a partir de 2001, o BNB apresentasse índices de Basileia que superaram o valor exigido pelo Banco Central (11\%), o que foi mantido até o final de 2010. No período 2001-10 (até junho), a única queda substancial do índice se deu entre os anos de 2006 e 2008, a qual pode, em termos gerais, ser creditada à crise financeira internacional, visto que o banco, tal qual o BNDES, buscou uma forte expansão nos seus empréstimos - os mesmos se expandiram a uma taxa real média de 40,4\% no biênio 2008/09 — como resposta aos efeitos mais imediatos da referida crise, sem que fosse observada uma correspondente elevação do patrimônio de referência do banco.

\footnotetext{
${ }^{19}$ Tal fato ocorreu devido à troca, entre o BNB e o Tesouro Nacional, de créditos de baixa qualidade por títulos do Tesouro no âmbito do Proef. Com esta operação, o Tesouro adquiriu os créditos de baixa remuneração e/ou difícil recuperação, eliminando sua participação na carteira de crédito do BNB e ampliando, por conseguinte, a parcela de créditos de boa qualidade na carteira de crédito do banco.
} 


\section{Gráfico 9}

BNB: ativo - operações de crédito e repasses (1998-10)* Variação \% real (IPCA)

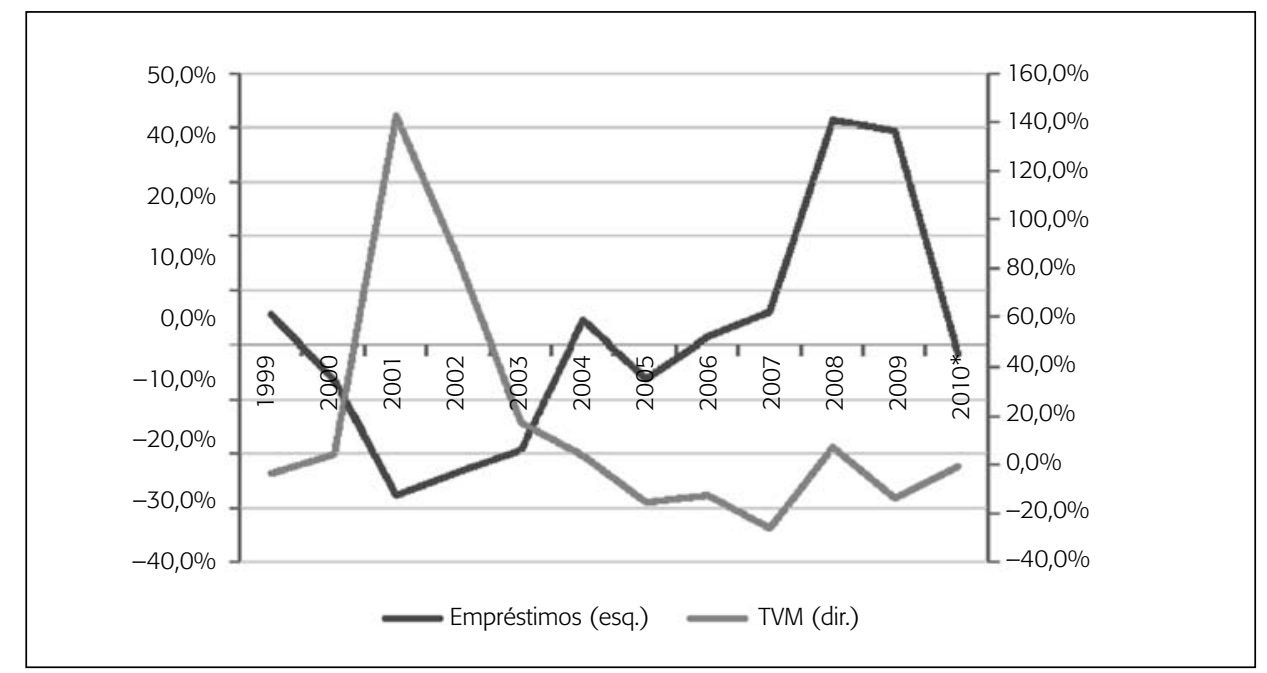

Fonte: Elaboração própria a partir de dados do BNB. * Referente ao primeiro semestre de 2010.

Gráfico 10

BNB: ativo - contas selecionadas (1998-10)*

Participação \% em relação ao total do ativo

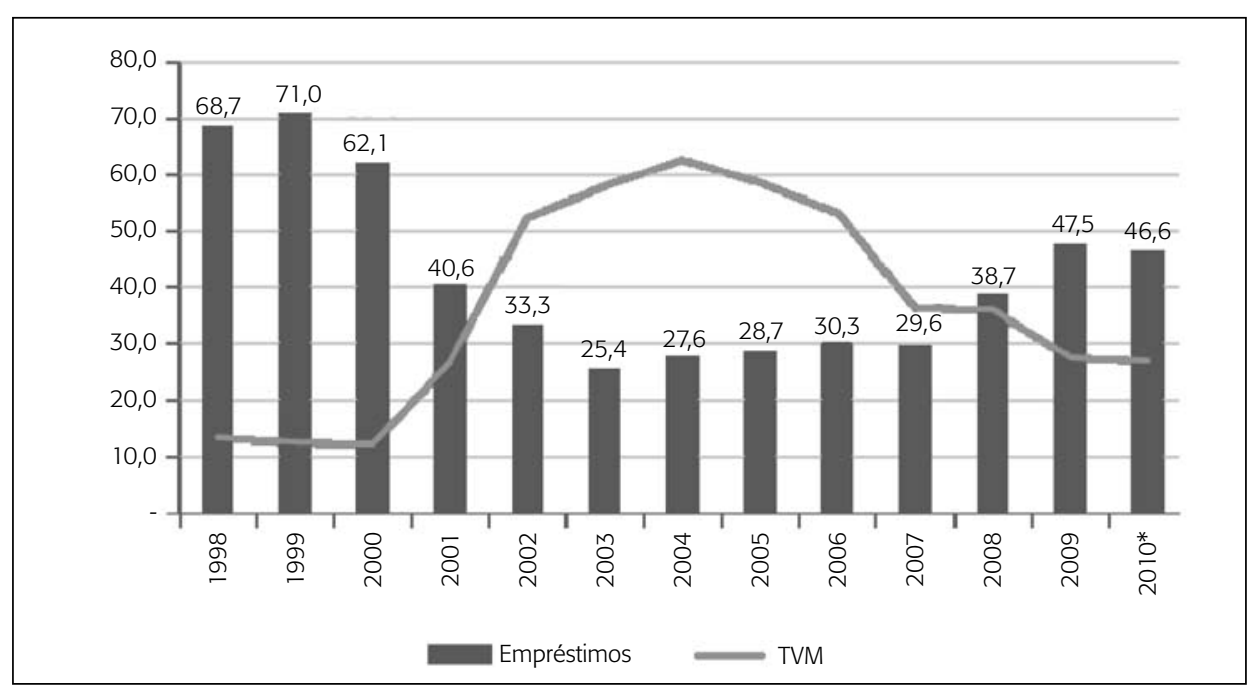

Fonte: Elaboração própria a partir de dados do BNB. * Referente ao primeiro semestre de 2010. 
As operações de crédito, contudo, só iniciaram um efetivo movimento de expansão a partir de 2004, o qual se consolida após 2006 e se acentua nos anos de 2008 e 2009. Neste período, quando se pode afirmar que o banco buscou mais explicitamente uma estratégia de expansão do crédito, o mesmo realizou um substantivo esforço para elevar a parcela de tomadores de boa qualidade na carteira. Tal fato fica evidenciado na elevação das operações de crédito classificadas como investment grade, que saem de $58 \%$ do total das operações em 2001 para cerca de 90\% a partir de 2007 (gráfico 11). Este movimento é fortemente baseado na expansão de créditos AA até 2005, o qual dá lugar a uma expansão mais intensa dos créditos A e B a partir de então. Aparentemente, após estabelecido um patamar satisfatório de créditos investment grade no total, o banco se permite uma ampliação dos tomadores relativamente mais arriscados dentro desta categoria. ${ }^{20}$

\section{Gráfico 11}

BNB: repasses e operações de crédito (2001-10)* Operações investment grade (AA, A e/ou B) em relação ao total da carteira - \%

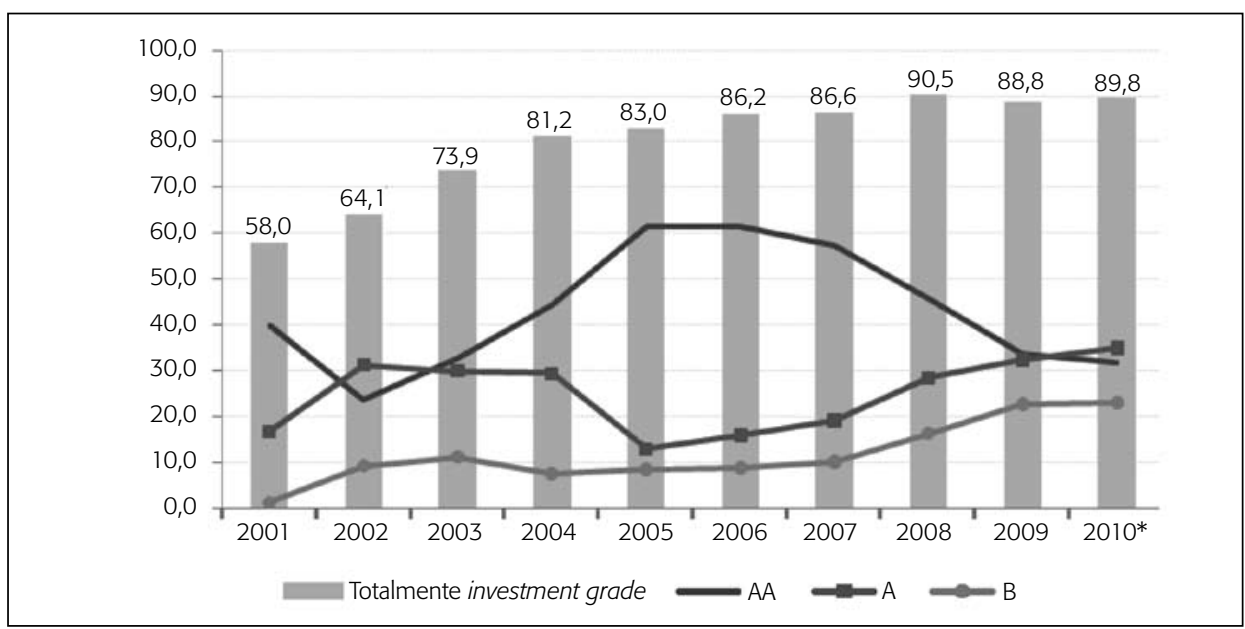

Fonte: Elaboração própria a partir de dados do BNB. * Referente ao primeiro semestre de 2010.

${ }^{20}$ Destaca-se que este movimento tem início antes da eclosão da crise financeira internacional. Ou seja, o mesmo não é uma resposta à crise, embora não se possa excluir a hipótese de ele ter sido amplificado pela mesma. 
A recomposição da carteira de crédito do BNB até 2005 permitiu, portanto, que houvesse uma significativa redução das provisões exigidas para risco de crédito - para créditos AA e A, a mesma é zero —, reduzindo desta forma a magnitude do ativo ponderado pelo risco e, por conseguinte, o patrimônio de referência exigido. Contudo, à medida que se eleva a parcela de créditos B, em um contexto de expansão do crédito sobre o total do ativo, aumenta-se a exigência por provisões e o patrimônio de referência exigido.

Há de se notar, por fim, que no caso do BNB a distinção entre créditos diretos e indiretos é pouco relevante. Estes últimos representaram menos de $5 \%$ do total de empréstimos ao longo de praticamente todo o período de análise (1998-10), excetuando-se os anos de 2006 e 2007, quando os mesmos atingem, respectivamente, $5,2 \%$ e $6,3 \%$ do total dos empréstimos. Neste sentido, os benefícios da elevação das operações indiretas observados no caso do BNDES não são relevantes para o BNB. Desta forma, a eventual redução do APR seria insignificante - e.g., 0,9\% do ativo total no ano de 2007 - o impacto sobre a diversificação da carteira também seria mínimo, assim como os efeitos sobre a capilaridade do banco, visto que o mesmo já conta com uma ampla rede de agências em todo o Nordeste para auxiliar no processo de distribuição do crédito e, como tal, possui uma elevada capilaridade.

Os impactos do Proef sobre o passivo, por sua vez, foram bem mais limitados do que o sugerido pelo programa. Sem embargo, a elevação do capital social da ordem de R 2,1 bilhões observada nos anos de 2001 e 2002 foi acompanhada de um forte ajuste na conta lucros/prejuízos acumulados e não houve uma elevação do capital de nível II referente aos repasses do FNE como previsto, o que fez com que o patrimônio de referência pouco se alterasse no período 2001-08 (gráfico 12). Somente em 2009, após a forte elevação dos empréstimos indicada acima, o BNB busca elevar o montante do patrimônio de referência, tal como indicado pelo próprio Banco: "Em julho de 2009, o BNB celebrou contrato de dívida subordinada com o FNE e foi autorizado pelo Banco Central do Brasil a considerar os valores do âmbito desse contrato como capital Nível II, com reflexo positivo no índice de Basileia da Instituição" (BNB, 2009). Como resultado, o índice se expandiu de 12,5\% em 2008 para $13 \%$ em 2009 e $13,9 \%$ em junho de 2010 , mesmo levando-se em conta a paralela expansão dos empréstimos concentrada em créditos de menor qualidade relativa (nível B).

Assim, a observância aos procedimentos regulamentares de Basileia pelo BNB exigiu uma profunda reestruturação da instituição, iniciada com a sua inclusão no Proef. Como visto, o Proef implicou uma redução da parcela dos empréstimos no total do ativo de nada menos que 45 pontos, tendo redu- 
zido substancialmente a capacidade emprestadora do mesmo e, assim, afetado negativamente o exercício das suas funções. Diferentemente do BNDES, a estratégia operacional do BNB esteve profundamente condicionada à necessidade de adequação às exigências regulamentares de Basileia. $\mathrm{O}$ banco só passa a gozar de maior autonomia em relação a Basileia a partir de 2009.

\section{Gráfico 12}

BNB: patrimônio de referência (2001-10)* $\mathrm{R} \$$ milhões de junho de 2010 (IPCA)

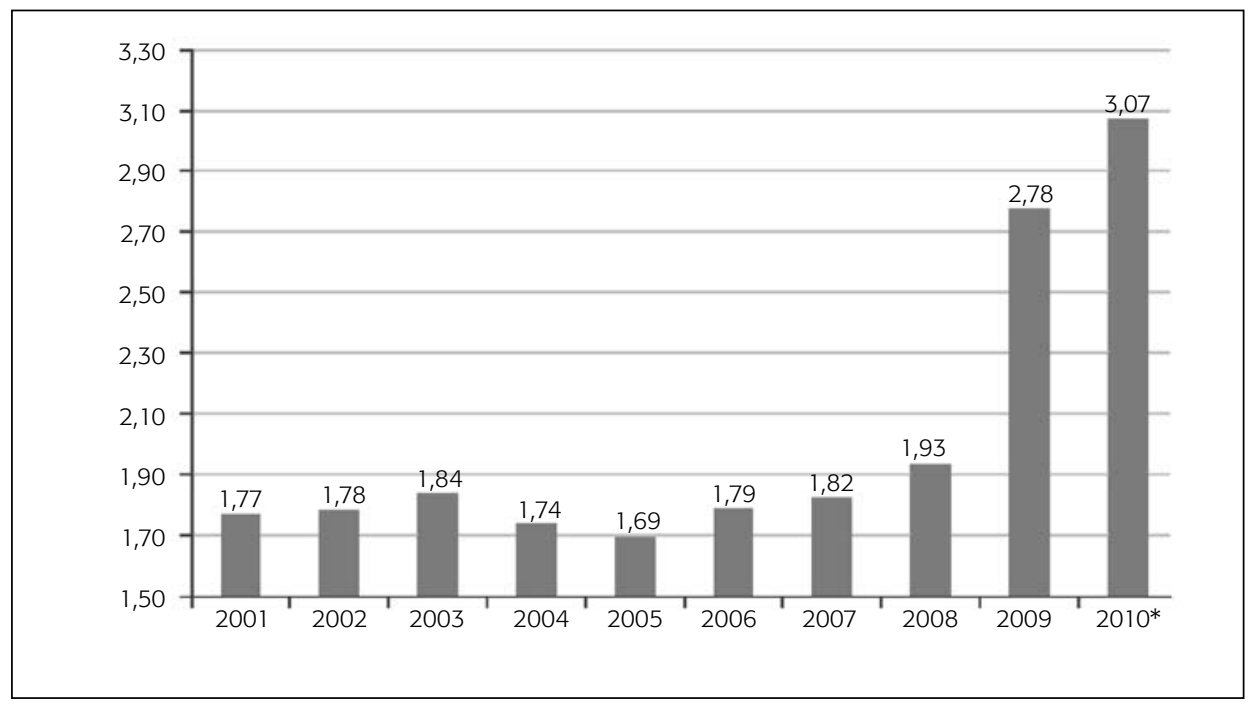

Fonte: Elaboração própria a partir de dados do BNB. * Primeiro semestre de 2010.

\section{Conclusão}

A despeito das dificuldades empíricas de se avaliar os impactos da implementação dos acordos de Basileia sobre os bancos de desenvolvimento brasileiros - não existem informações disponíveis sobre mudanças internas de procedimento (e.g., modelos de gestão de risco, reclassificação de operações de crédito etc.) - , podemos concluir que as duas instituições analisadas, o BNDES e o $\mathrm{BNB}$, foram afetadas de modo assimétrico.

No caso do BNDES, a sua obediência aos Acordos não o impediu de executar suas funções de modo satisfatório: o volume de desembolsos ao longo do período 1998-10 foi crescente, atingindo recordes históricos, e a rede de influência do banco aumentou significativamente, especialmente após 2007. 
O BNDES manteve uma estratégia operacional relativamente autônoma às exigências regulamentares, mas as mesmas provocaram algumas limitações: as operações de crédito passaram a ter elevada concentração em operações investment grade, o que parece indicar a necessidade de manter controlado o ativo ponderado pelo risco. Como consequência, a taxa de expansão das operações de crédito entre 2008 e 2010 - com ênfase para o crescimento das operações diretas - parece ter sido afetada pela necessidade de ampliação da parcela de ativos associados a um menor grau de risco.

Já no caso do BNB, sua obediência a Basileia exigiu uma profunda reestruturação de sua estratégia operacional. A mesma esteve essencialmente condicionada à necessidade de adequação às exigências regulamentares, tendo o banco ganhado maior autonomia somente a partir de 2009, quando amplia seu patrimônio de referência por meio da inclusão de instrumentos de capital de nível II ligados ao FNE. No período imediatamente após a implementação de Basileia, o BNB teve sua capacidade emprestadora substancialmente reduzida, o que prejudicou intensamente o exercício de suas funções. Contudo, como ressaltado pelo Banco,

Há de se considerar que o Banco do Nordeste, como órgão de desenvolvimento regional e na qualidade de agente de programas de fomento do Governo Federal, tem entre seus encargos as aplicações de recursos vinculados a programas governamentais, que, dadas as suas especificidades, independem de enquadramento às regras de alavancagem e limites definidos para as operações de crédito (BNB, 2001).

A citação acima parece indicar que, para o banco, Basileia é um marco inadequado para orientar os modelos de gestão de risco, o que seria válido não só para o BNB, mas, de modo mais geral, para qualquer banco de desenvolvimento. Tal afirmação, contudo, não significa que tais instituições não devam adotar uma estratégia de gestão de riscos, nem que as mesmas não devam estar sujeitas a qualquer tipo de regulação. $O$ indicado na citação acima, e referendado por autores como Sobreira (2009), é que é fundamental o regulador - no caso brasileiro, o Banco Central do Brasil - reconhecer que a ação destas instituições deva se pautar por modelos de gestão de risco compatíveis com as peculiaridades dos bancos de desenvolvimento, notadamente quando operando em países em desenvolvimento, e, como tal, que os mesmos possam executar adequadamente suas missões. 


\section{Referências}

BANCO CENTRAL DO BRASIL. Resolução 2.099, de 17 de agosto de 1994.

. Resolução 2.212, de 16 de novembro de 1995. . Resolução 2.283, de 5 de junho de 1996a.

. Resolução 2.302, de 25 de julho de 1996b.

. Circular 2.784, de 27 de novembro de 1997.

. Resolução 2.543, de 26 de agosto de 1998.

. Resolução 2.682, de 21 de dezembro de 1999.

. Resolução 2.802, de 21 de dezembro de 2000.

. Resolução 2.837, de 30 de maio de 2001.

. Relatório 50 Maiores Bancos. Vários números. 2001-10.

. Relatório de Estabilidade Financeira. Vários números. 2002-10.

. Comunicado 12.746, de 9 de dezembro de 2004.

. (2007). Comunicado 16.137, de 27 de setembro de 2007.

. Basileia II no Brasil. 2010. Disponível em <www.bcb.gov.br/nor/basileia/

BasileiaIInaweb.pdf > . Acesso em: 28 dez. 2010.

BANCO DO NORDESTE DO BRASIL. Demonstrações Contábeis. Banco e FNE. 2001.

. Estatuto social do Banco do Nordeste do Brasil S.A. Fortaleza: Banco do Nordeste do Brasil, 2009.

BCBS (BASEL COMMITTEE ON BANKING SUPERVISION). International convergence of capital measurement and capital standards. Basel: Bank for International Settlements, July 1988.

. Amendment to the capital accord to incorporate market risks. Basel: Bank for International Settlements, Jan. 1996.

. International convergence of capital measurement and capital standards: a revised framework. Basel: Bank for International Settlements, June 2004.

BNDES. BNDES 50 Anos. Rio de Janeiro: BNDES, 2002.

. Basileia e administração de riscos. O novo Acordo da Basileia e suas implicações para o BNDES. Relatório Parcial I, 2007. Mimeografado. 
. Missão e Visão. 2010. Disponível em: <www.bndes.gov.br/SiteBNDES/bndes/bndes_pt/Institucional/O_BNDES/A_Empresa/missao_e_visao.html >. Acesso em: 10 jan. 2011.

BRASIL. Constituição Federal de 1988.

. Medida provisória (MP) 2.196, de 28 de junho de 2001.

CARVALHO, F. Inovação financeira e regulação prudencial: da regulação de liquidez aos acordos da Basileia. In: SOBREIRA, R. Regulação financeira e bancária. São Paulo: Atlas, 2005. cap. 6.

CASTRO, L. Regulação financeira: teoria, Acordos de Basileia e a experiência recente do BNDES. Tese (doutorado) - Instituto de Economia, Universidade Federal do Rio de Janeiro, Rio de Janeiro, 2009.

DE BANDT, O.; HARTMANN, P. Systemic risk: a survey. ECB Working Paper, n. 35 , Nov. 2000.

GIAMBIAGI, F.; RIECHE, F.; AMORIM, M. (2009). As finanças do BNDES: evolução recente e tendências. Revista do BNDES, Rio de Janeiro, v. 16, n. 31, p. 3-40, jun. 2009.

MINISTÉRIO DA FAZENDA. Fortalecimento das instituições financeiras federais, em 22/06/2001. 2001a. Disponível em: <www.fazenda.gov.br/portugues/releases/2001/r010622.asp>. Acesso em: 8 jan. 2011.

. Banco do Nordeste implementa ajustes para potencializar ações na região, em 22/06/2001. 2001b. Disponível em: <www.fazenda.gov.br/portugues/releases/2001/r010622b.asp>. Acesso em: 8 jan. 2011.

PRADO, L.C.; MONTEIRO FILHA, D. O BNDES e os acordos de capital de Basileia. Revista do BNDES, Rio de Janeiro, v. 12, n. 23, p. 177-200, jun. 2005.

PROCHNIK, M.; MACHADO, V. Fontes de recursos do BNDES 1995-2007. Revista do BNDES, Rio de Janeiro, v. 14, n. 29, p. 3-34, jun. 2008.

SOBREIRA, R. Development banks and Basel II: some assessments. Paper presented at the II Conference of the Brazilian Keynesian Association (AKB). Porto Alegre, 9-11 Sep., 2009.

; PAULA, L. F. de. The 2008 Financial crisis and banking regulation in Brazil: the role of the prudential regulation. Journal of Innovation Economics, n. 6, Dec. 2010.

; ZENDRON, P. Implications of Basel II for national development banks. In: GNOS, C.; ROCHON. L.P. (Ed.). Credit, money and macroeconomic policy. Aldershot: Edward Elgar, 2011. 


\section{Anexo}

Gráfico A. 1

BNDES consolidado: dívida subordinada elegível a capital (DSEK)

Cálculo pré-resolução 2.837/2001 (DSEK) e pós-resolução

$(\mathrm{DSEK}=50 \%(\mathrm{PL}-$ Res. Reav. $)-\mathrm{R} \$$ mil

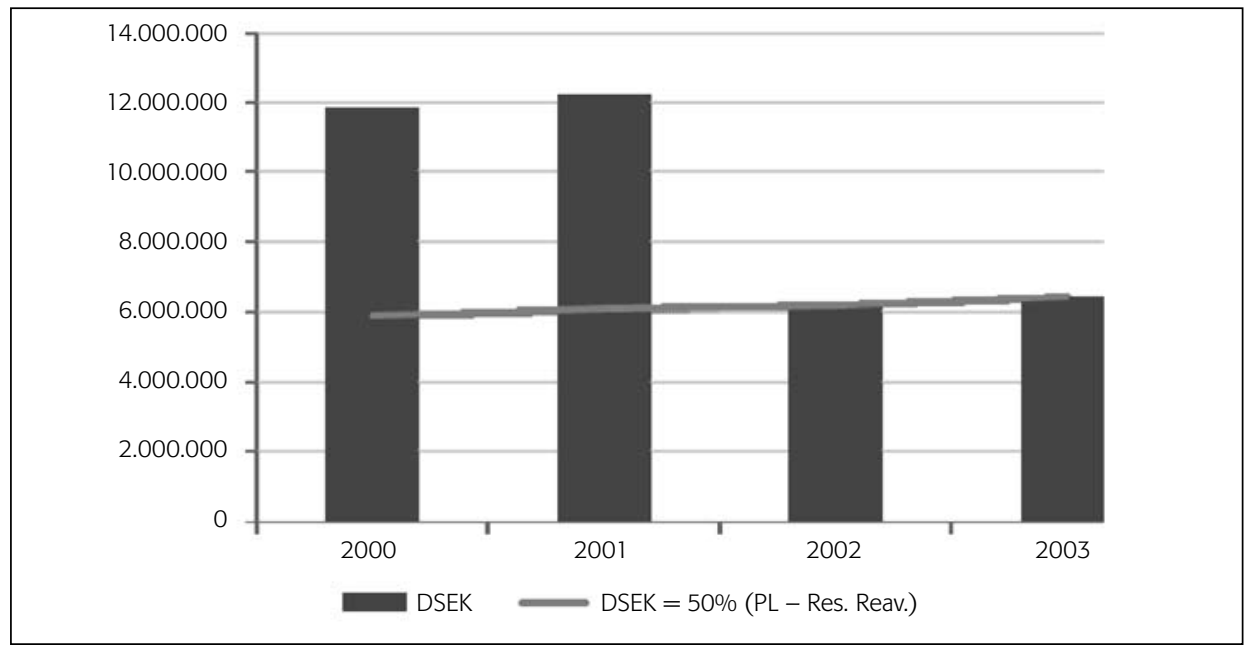

Fonte: Elaboração própria a partir de dados do BNDES.

Gráfico A.2

BNDES: taxa de variação dos empréstimos (2008-10)*

Variação \% real verificada e projetada**

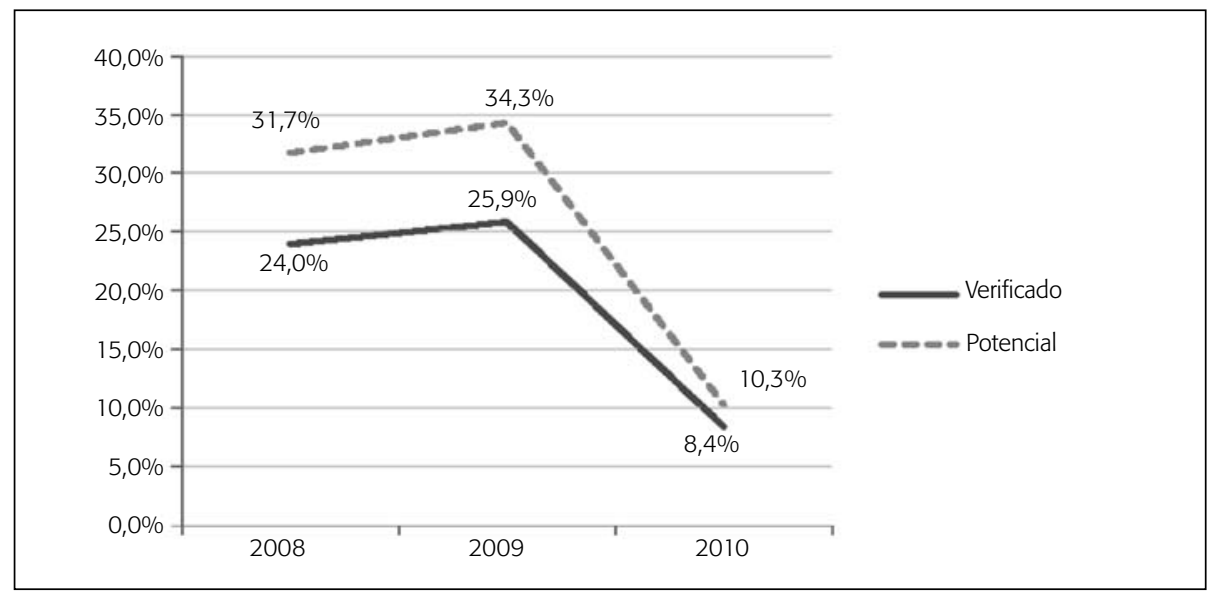

Fonte: Elaboração própria a partir de dados do BNDES. * Referente ao primeiro semestre de 2010. ** Calculada a partir da soma do montante de variação da rubrica TVM às operações de crédito. 


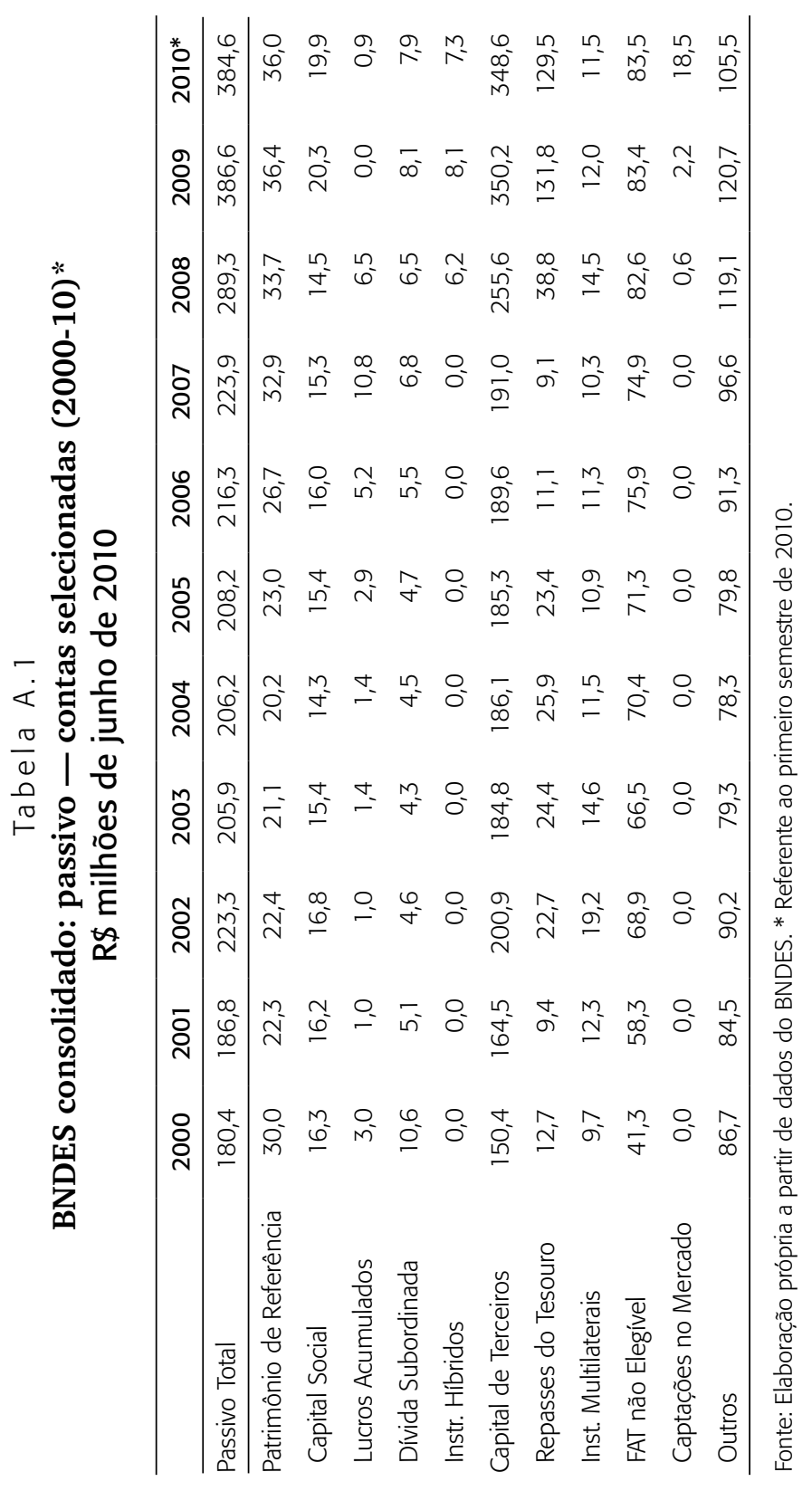

